Available online at: http://journal.unj.ac.id

Jurnal
Pensil

Journal homepage: http://journal.unj.ac.id/unj/index.php/ipensil/index

\title{
INVESTIGASI KAWASAN RAWAN BENCANA LONGSOR DENGAN MENGGUNAKAN SISTEM INFORMASI GEOGRAFIS STUDI KASUS KABUPATEN MADIUN
}

\section{INVESTIGATION OF ASLIDE DISASTER AREAS USING GEOGRAPHIC INFORMATION SYSTEMS CASE STUDY OF MADIUN DISTRICT}

\author{
Risal Ardiansyah Putra', Amelia Rosana Putri ${ }^{2}$, Faried Abdillah Santoso ${ }^{3}$ \\ ${ }^{1,2,3}$ Institut Teknologi Sepuluh November \\ 1. risalsyahputra66@gmail.com, 2ameliaadict@gmail.com 3aried.ghost@gmail.com
}

\begin{abstract}
Abstrak
Secara geografis meskipun Indonesia memiliki potensi sumber daya
P-ISSN: $2301-8437$

E-ISSN: $\underline{2623-1085}$

ARTICLE HISTORY

Accepted:

7 Maret 2021

Revision:

14 Mei 2021

Published:

31 Mei 2021

ARTICLE DOI:

$\overline{\overline{10.21009 / \text { jpensil.v10i2.20253 }}}$

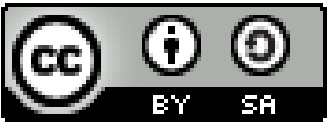

Jurnal Pensil :

Pendidikan Teknik

Sipil is licensed under a

Creative Commons

Attribution-ShareAlike

4.0 International License

(CC BY-SA 4.0). alam yang luar biasa, namun Indonesia juga rawan terhadap bencana alam, khususnya tanah longsor. Hal ini dikarenakan banyaknya dataran tinggi dan pengunungan, termasuk Kabupaten Madiun yang memiliki Gunung Wilis. Kabupaten Madiun merupakan daerah yang terkena dampak erosi. Oleh karena itu, penelitian ini mengkaji daerah rawan longsor di Kabupaten Madiun menggunakan Sistem Informasi Geografis (SIG) dengan data sekunder bersumber dari USGS SRTM data BKMG, Google Earth dan data BPS Kabupaten Madiun yang diolah menggunakan software ArcGis 10.7 dengan metode Union Overlay Analysis berdasarkan pembobotan pada peta parameter bencana longsor. Data yang diolah menghasilkan peta kepadatan penduduk, geologi, curah hujan, kemiringan lereng, dan peta KRB Longsor di Kabupaten Madiun. Peta KRB Longsor menunjukkan bahwa Kabupaten Madiun memiliki kerawanan (aman) terhadap erosi yang relatif rendah. Wilayah yang berpotensi mengalami erosi berada di bagian barat antara Kecamatan Pilangkenceng, Balerejo, Jiwan, dan sebagian Kecamatan Kebonsari dan Dolopo dengan luas 192,07 km² untuk kerawan tinggi dan $1,39 \mathrm{~km}^{2}$ untuk kerawanan sangat tinggi. Pasalnya, kabupaten-kabupaten tersebut memiliki curah hujan ekstrem dengan intensitas di atas $150 \mathrm{~mm}$ dan kepadatan penduduk yang relatif padat hingga sangat padat. Peta KRB Longsor Kabupaten Madiun dapat menjadi sumber referensi bagi warga dan masyarakat untuk menentukan titik rawan longsor di Kabupaten Madiun sehingga dapat mempersiapkan mitigasi bencana longsor untuk meminimalisir dampak dan kerugian yang terjadi.
\end{abstract}

Kata kunci: Longsor, GIS, Mapping 


\begin{abstract}
Geographically, although Indonesia has the potential for tremendous natural resources, it is also prone to natural disasters, particularly landslides. It is due to the large number of highlands and mountains, including Madiun Regency which has Mount Wilis. Madiun Regency is an area affected by landslides. Therefore, this paper aimed to investigate landslide hazard areas (KRB) in Madiun Regency using a Geographic Information System (GIS) with secondary data sourced from SRTM USGS, BMKG data, Google Earth, and BPS data for Madiun Regency which was processed using ArcGis 10.7 software with the Union Overlay Analysis method based on weighting on the landslide disaster parameter map. The processed data produced a map of population density, geology, rainfall, slope, and a map of the Landslide KRB in Madiun Regency. The Landslide KRB Map shows that Madiun Regency has a relatively low (safe) hazard to landslides. The areas with the potential to experience landslides are in the west, including Pilangkenceng, Balerejo, Jiwan Districts, and parts of Kebonsari and Dolopo Districts with an area of $192.07 \mathrm{~km} 2$ for high hazard and $1.39 \mathrm{~km} 2$ for very high hazard. It is because these districts have extreme rainfall with an intensity of above $150 \mathrm{~mm}$ and a relatively dense to very dense population density. The Landslide KRB Map of Madiun Regency can be a reference source for residents and the public to determine the hazard points of landslides in Madiun Regency so that they can prepare for landslide disaster mitigation to minimize the impacts and losses that occur.
\end{abstract}

Keywords: Landslide, GIS, Mapping

\section{Pendahuluan}

Indonesia memiliki potensi sumber daya alam yang luar biasa akan tetapi indonesia juga rawan terhadap potensi bencana alam, terutama bencana tanah longsor yang terjadi di $45 \%$ luas daerah Indonesia (Susilo, 2008). Tanah longsor merupakan pergerakan material penyusun lereng yang berupa batuan, tanah, dan material lainnya yang bergerak keluar dari lereng (Yuniarta et al., 2015). Kondisi lempeng tektonik di Indonesia membuat morfologi ketinggian, patahan, dan batuan vulkanik yang mudah rapuh serta kondisi tropis dengan curah hujan yang tinggi menyebabkan potensi bencana tanah longsor menjadi tinggi di Indonesia (Naryanto et al., 2019). Hal ini juga terjadi pada Kabupaten Madiun. Hal tersebut disebabkan kabupaten Madiun juga terletak di kaki Gunung Wilis seperti yang dilansir oleh BPBD kabupaten Madiun pada tanggal 15 Februari 2021 terjadi tanah longsor akibat curah hujan yang tinggi pada 6 titik di wilayah Gunung Wilis, oleh sebab itu kelerangan pada daerah tersebut berpotensi terjadi bencana tanah longsor. Walaupun hal ini merupakan salah satu faktor penyebab bencana tanah longsor, tetapi juga terdapat faktor penyebab tanah longsor lainnya. Faktor penyebab tersebut dibedakan menjadi dua yaitu faktor alam dan faktor manusia.

Faktor alam tersebut meliputi kelerengan, curah hujan, geologi dan sebagainya (Effendi, 2016). Sedangkan faktor manusia meliputi kepadatan penduduk dan juga tindakan manusia yang dapat meningkatkan bencana tanah longsor. Diantara faktor - faktor tersebut, faktor manusia yang dapat dikendalikan. Hal ini berhubungan dengan pertumbuhan penduduk pada suatu wilayah sehingga menyebabkan kepadatan penduduk dan hal ini dapat menyebabkan kerugian yang besar jika kepadatan penduduk terjadi pada daerah yang memiliki potensi bencana tanah longsor. 
Untuk mengurangi resiko bencana tanah longsor tersebut, dibutuhkan kesiapan sebelum bencana tersebut terjadi (mitigasi bencana). Untuk hal tersebut dapat dilakukan identifikasi Kawasan Rawan Bencana (KRB) tanah longsor pada Kabupaten Madiun untuk sebagai salah satu mitigasi bencana yang dapat dilakukan. Hal ini juga dapat mempengaruhi tata ruang berdasarkan peta KRB tanah longsor tersebut, sehingga meminimalkan dampak dari bencana tanah longsor. Hal ini dapat dibantu oleh pemodelan peta yang menggunakan Sistem Informasi Geografis (SIG) untuk melakukan analisa keruangan (Buchori, 2005). Hal ini dapat dilakukan dengan meggunakan metode tumpang susun (overlay) pada beberapa faktor penyebab bencana tanah longsor seperti kemiringan lereng, curah hujan, geologi dan faktor manusia dan menghasilkan hasil peta KRB yang cukup akurat untuk mitigasi bencana tanah longsor tersebut.

\section{Geologi Regional}

Secara geografis Kabupaten Madiun terletak di $7^{\circ} 12^{\prime}$ sampai dengan $7^{\circ} 48^{\prime} 30$ " Lintang Selatan dan $111^{\circ} 25^{\prime} 45^{\prime}$ "sampai dengan $111^{\circ} 51$ ' Bujur Timur. Berdasarkan peta geologi Kabupaten Madiun, terletak pada kaki gunung Wilis. Kabupaten Madiun sebagaian besar wilayahnya terdiri dari Morfoset Argokalangan yang merupakan morfoset termuda dari Gunung Wilis yang mengandung endapan tefra dan lava andesit horenblenda dengan luas sebesar 314,307 $\mathrm{km}^{2}$ (Kabupaten Madiun, 2019). Selain Morfoset Argohalangan pada Kabupaten Madiun juga sebagaian besar mengandung aluvial yang memiliki kemampuan infiltrasi yang cukup baik dan juga terdapat kadar mineral dan organisme yang cukup dengan luas sebesar $309,763 \mathrm{~km}^{2}$. Setelah Aluvial dan morfoset Argohalangan terdapat Morfonit Notopuro yang merupakan endapan dari breksi gunung api, tuf dan aglomerat dengan luas sebesar 169,137 km². Selain tersebut pada kabupaten Madiun juga terdapat beberapa formasi penyusun seperti Formasi Kalibeng, Formasi Pucangan, Breksi Pandan, Formasi Kabuh, Morfoset
Ngebel, Batuan Gunungapi Wilis, Morofset Sedudo, Morfoset Patukbenteng-Jeding dan Danau. Secara detail geologi Kabupaten Madiun dapat dilihat pada gambar 1 seperti berikut

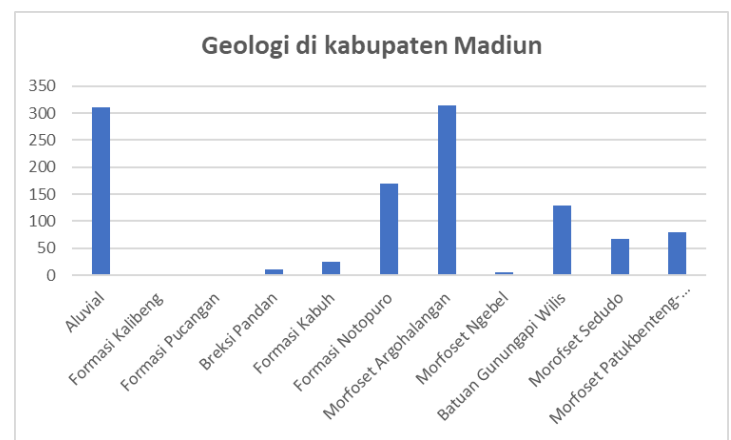

Gambar 1. Persebaran Geologi Kabupaten Madiun (Kabupaten Madiun, 2019)

\section{Curah Hujan}

Curah hujan merupakan satuan jumlah air selama periode tertentu dalam satuan milimeter hal ini berkaitan dengan jumlah air yang mengalir. Curah hujan terbagi menjadi beberapa bagian menurut waktu pengamatannya, yaitu curah hujan harian, curah hujan bulanan, curah hujan tahunan, dan curah hujan maksimum (Susilowati \& Sadad, 2015). Di Indonesia memiliki curah hujan yang cukup bervariasi berdasarkan ketinggian daerahnya. Dan curah hujan juga merupakan salah satu yang dapat menyebabkan bencana tanah longsor. Semakin tinggi intensitas curah hujan tersebut maka semakin tinggi potensi bencana tanah longsor terjadi, hal ini juga dipengaruhi oleh ukuran butir batuan. Hal ini berkaitan dengan energi kinetik yang dapat menghancurkan agregat-agregat tanah (Utomo, 1989). Dan pada penelitian ini menggunakan skoring berdasarkan Badan Meteorologi, Klimatologi, dan Geofisika (BMKG) sebagai berikut

Tabel 1. Skor Faktor Curah Hujan

\begin{tabular}{lll}
\hline Curah Hujan & Klarifikasi & Skor \\
\hline $0.5-20 \mathrm{~mm} /$ hari & Hujan ringan & 1
\end{tabular}




\begin{tabular}{lll}
\hline $20-50 \mathrm{~mm} /$ hari & Hujan sedang & 2 \\
\hline $50-100 \mathrm{~mm} /$ hari & Hujan lebat & 3 \\
\hline $100-150 \mathrm{~mm} /$ hari & Hujan sangat lebat & 4 \\
\hline$>150 \mathrm{~mm} /$ hari & Hujan ekstrem & 5 \\
\hline
\end{tabular}

Kelerengan/Kemiringan

Kemiringan lereng merupakan salah satu topografi pada suatu tempat yang diakibatkan tenaga eksogen dan endogen sehingga terjadi perbedaan ketinggian titik (Kartasapoetra, 1986). Kekuatan gravitasi yang menekan tanah-tanah miring melebihi daya tahan tanah untuk mempertahankan posisinya membuat tanah menjadi longsor (Bakri et al., 2019). Kelerengan juga merupakan salah satu faktor yang mempengaruhi terjadinya longsor dan biasanya bencana longsor terjadi pada lereng yang curam (Guillard dan Zezere, 2012). Dan secara geomorfologi, kabupaten Madiun terletak di kaki Gunung Wilis, sehingga kabupaten Madiun ini memiliki tingkat lereng yang cukup curam. Dan pada penelitian ini menggunakan skoring berdasarkan Penyusunan Rehabilitasi Lahan dan Konservasi Tanah tahun 1986 sebagai berikut

Tabel 2. Skor Faktor Kelerengan/ Kemiringan

\begin{tabular}{lll}
\hline Kelerengan & Klarifikasi & Skor \\
\hline$<8 \%$ & Datar & 1 \\
\hline $8-15 \%$ & Landai & 2 \\
\hline $15-25 \%$ & Agak Curam & 3 \\
\hline $25-45 \%$ & Curam & 4 \\
\hline$>45 \%$ & Sangat Curam & 5 \\
\hline
\end{tabular}

Bencana Tanah Longsor
Tanah longsor merupakan salah satu kejadian alam yang disebabkan oleh faktor alam dan faktor manusia. Tanah longsor ini biasanya terjadi pada daerah dataran tinggi pada musim penghujan. $\mathrm{Hal}$ ini juga diakibatkan Indonesia yang memiliki moroflogi tinggi, patahan dan batuan vulkanik yang rapuh. Hal ini menyebabkan daerah ini rawan akan terjadinya tanah longsor (Naryanto, 2013). Longsor juga merupakan perpindahan massa batuan karena terjadinya gravitasi atau terdapatnya ketidakseimbangan gaya pada suatu lereng. Hal ini berhubungan dengan bentang alam suatu daerah, dan kerusakan yang diakibatkan oleh bencana tanah longsor ini tidak hanyak merusak fasilitas perkotaan namu juga dapat memakan korban jiwa dan juga mengganggu aktivitas secara pembangunan dan ekonomi daerah tersebut (Hardiyatmo, 2006). Kepadatan penduduk pada suatu daerah berlereng juga menjadi salah satu faktor penyebab tanah longsor, karena semakin banyak populasi yang ada akan menambah beban yang harus ditahan lereng tersebut (Pranatasari et al., 2017).

\section{Metode Penelitian}

Lokasi Penelitian

Penelitian ini dilakukan di Kabupaten Madiun dengan menggunakan data sekunder yang diambil dari tahun 2019 hingga 2020, hal ini disebabkan data sekunder yang memiliki informasi secara lengkap terkait faktor-faktor bencana alam tanah longsor terdapat pada periode tersebut.

Alat dan Bahan

Alat dan bahan yang digunakan sebagai berikut: Software ArcGis 10.7, data sekunder dari Peta Admintrasi Kabupaten Madiun, Peta curah hujan Jawa Timur dari BMKG bulan desember 2020, Peta USGS 2014, Peta Geologi Kabupaten Madiun dan Data penduduk dari Badan Pusat Statistik Kabupaten Madiun. 
Metode Penelitian

Dalam penelitian ini terdapat beberapa tahapan sebagai berikut:

Mengumpulkan Informasi dan Data

Pada tahap pertama dalam metode ini dilakukan pengumpulan data dan informasi dari penelitian yang telah ada maupun dari beberapa referensi berupa data sekunder seperti Peta Admintrasi Kabupaten Madiun, Peta curah hujan Jawa Timur dari BMKG bulan desember 2020, Peta USGS 2014, Peta Geologi Kabupaten Madiun dan Data penduduk dari Badan Pusat Statistik Kabupaten Madiun.

Scoring dan Pembobotan Parameter

Berdasarkan data sekunder yang didapatkan diolah menjadi beberapa peta yang dibutuhkan untuk membuat peta Kawasan Rawan Bencana Tanah Longsor seperti peta kependudukan, peta curah hujan, peta geologi dan peta kemiringan lereng. Scoring disini bertujuan untuk memberikan skor pada masing-masing parameter sesuai dengan pembagian skor yang terdapat pada tabel 1 dan tabel 2 . Berdasarkan tabel tersebut menunjukkan setiap parameter memiliki skor yang berbeda. Seperti tabel 1 yang memberikan skor berdasarkan intesitas curah hujan yang terjadi semakin tinggi intensitasnya semakin tinggi skor yang diberikan dan tabel 2 memberikan skor yang berdasarkan kemiringan lereng semakin curam maka skor yang diberikan semakin tinggi.

Overlay (Tumpang Susun Peta)

Setelah mendapatkan beberapa parameter yang dibutuhkan dalam pembuatan peta kawasan rawan bencana tanah longsor. Selanjutnya dilakukan tumpang susun terhadap peta dari beberapa parameter tersebut untuk menghasilkan peta kerawanan tanah longsor. Pada tahap tumpang susun (overlay) menggunakan arctoolboc ArcGis 10.7 yaitu Analysis Union Overlay. Overlay yang dilakukan menjumlahkan nilai-nilai yang terdapat pada peta masing-masing parameter. Berikut diagram alur dari pembuatan peta kawasan rawan bencana tanah longsor tersebut. 


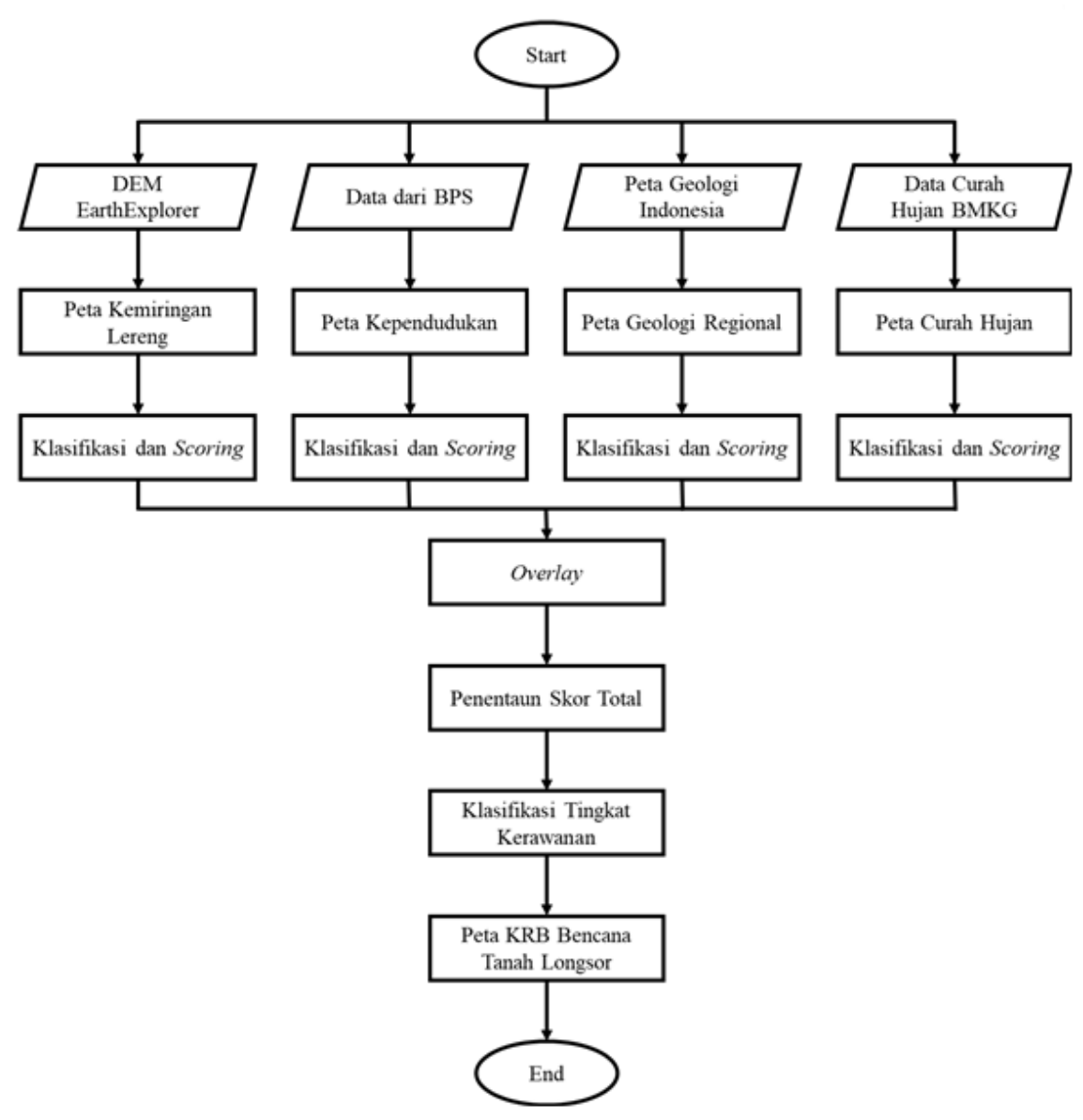

Gambar 2. Diagram Alur Pembuatan Peta KRB Tanah Longsor

Penentuan Skor Total dan Pembagian Interval

Berdasarkan peta kerawanan berdasarkan arctoolboc ArcGis 10.7 yaitu Analysis Union Overlay maka dilakukan penjumlahan pembobotan pada hasil akhir dari masing-masing paramter seperti curah hujan, geologi, kemiringan dan

\section{Hasil Penelitian dan Pembahasan}

Berdasarkan peta parameter dari peta kawasan rawan bencana tanah longsor dihasilkan beberapa sebagai berikut kependudukan. Berdasarkan hal tersebut maka diperoleh nilai total yang dapat digunakan untuk menentukan daerah rawan bencana tanah longsor. Setelah mendapatkan skor total tersebut maka dilakukan scoring yang membagi daerah kerawanan berdasarkan nilai total tersebut.

Peta Kemiringan Lereng

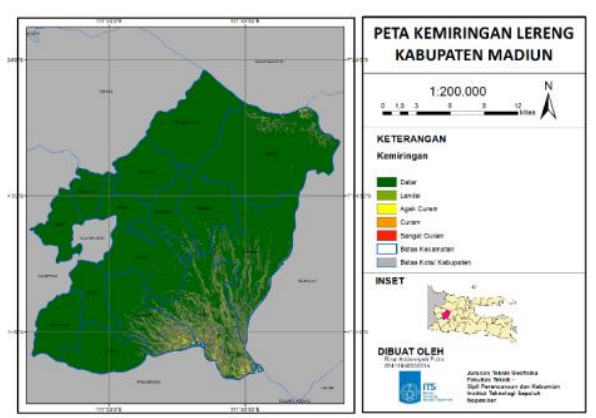




\section{Gambar 3. Gambar Peta Kemiringan Lereng Kabupaten Madiun}

Berdasarkan gambar 3 menunjukkan peta kemiringan lereng Kabupaten Madiun. Berdasarkan tabel 2 menunjukkan pembagian lereng berdasarkan Penyusunan Rehabilitasi Lahan dan Konservasi Tanah tahun 1986. Pada tabel 2 tersebut menunjukkan kondisi lereng yang berbedabeda. Berdasarkan tabel tersebut kemiringan lereng dibagi menjadi lima bagian yaitu datar $(0-8 \%)$, landai $(8 \%-15 \%)$, agak curam (15\%-25\%), curam $(25 \%-45 \%)$ dan sangat curam dengan slope diatas $45 \%$. Berdasarkan gambar 3 menunjukkan bahwa pada Kabupaten Madiun memiliki daerah yang dominan datar dengan slope relative rendah dibawah 8\%. Akan tetapi pada daerah Kabupaten Madiun juga terdapat puncak gunung dari Gunung Wilis sehingga terdapat beberapa daerah yang memiliki slope yang relatif agak curam yang ditunjukkan oleh warna kuning yang dominan terletak pada Kecamatan Karee dan terdapat juga di kecamatan disekitarnya seperti Kecamatan Dagangan, Gemarang, Mejayan, Wungu, Wonosari dan beberapa daerah sekitarnya. Dan berdasarkan gambar tersebut menunjukkan bahwa Kabupaten Madiun tidak memiliki lereng yang sangat curam bahkan lereng dengan slope 25\%$45 \%$ juga sedikit yang terdapat pada daerah tersebut. Sehingga dapat diketahui bahwa daerah kabupaten Madiun hanya memiliki slope yang dominan dari $0 \%$ hingga $25 \%$. Lereng merupakan salah satu faktor penyebab terjadinya tanah longsor. Sehingga lereng yang memiliki slope yang tinggi maka semakin tinggi juga potensi terjadinya bencana alam berupa tanah longsor, karena dengan semakin tinggi slope suatu lereng maka kestabilan lereng tersebut semakin tidak stabil dan jika lereng tersebur relative datar, maka memiliki kestabilan yang stabil. Berdasarkan gambar 3 menunjukkan bahwa daerah yang relative terjadi bencana longsor adalah kecamatan Dagangan, Gemarang, Mejayan, Saradan, Wungu, Wonosari dan beberapa daerah sekitarnya.

\section{Peta Curah Hujan}

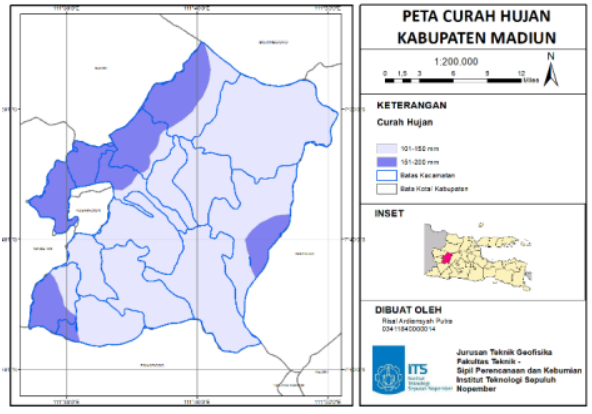

Gambar 4. Gambar Peta Curah Hujan Kabupaten Madiun

Berdasarkan gambar 4 menunjukkan peta curah hujan pada daerah Kabupaten Madiun. Berdasarkan tabel 1 menunjukkan pembagian curah hujan dari Badan Meteorologi, Klimatologi, dan Geofisika (BMKG) yang dinyatakan berdasarkan satuan jumlah air selama sehari dalam satuan milimeter hal ini berkaitan dengan jumlah air yang mengalir. Berdasarkan BMKG curah hujan dibagi menjadi lima yaitu hujan ringan, hujan sedang, hujan lebat, hujan sangat lebat dan hujan ekstrem. Berdasarkan gambar 4 menunjukkan bahwa daerah Kabupaten Madiun memiliki curah hujan yang relatif tinggi dikarenakan hampir semua daerah terjadi hujan sangat lebat dengan intensitas (101-150 mm). Bahkan terdapat di beberapa wilayah pada Kabupaten Madiun terjadi hujan ekstrem yang memiliki intensitas diatas $150 \mathrm{~mm}$. Curah hujan juga salah satu faktor penyebab terjadinya tanah longsor selain kemiringan lereng. Berdasarkan hal ini menunjukkan bahwa semakin tinggi curah hujan pada suatu daerah maka daerah tersebut berpotensi tanah longsor, hal ini juga dapat didukung jika pada daerah tersebut tidak memiliki kemampuan infiltrasi yang baik sehingga potensi bencana tanah longsor juga semakin tinggi. Sehingga berdasarkan gambar 4 daerah kabupaten Madiun memiliki curah hujan yang relatif tinggi sehingga seluruh kabupaten Madiun berdasarkan curah hujan dapat berpotensi 
terjadi tanah longsor terutama pada daerah yang memiliki curah hujan ekstrem seperti Kecamatan Pilangkenceng, Balerejo, Madiun, Sawahan, Jiwan, Kebonsari dan beberapa desa dari Kecamatan Gemarang dan Dolopo.

Gambar 5 menunjukkan peta kepadatan penduduk daerah Kabupaten Madiun. Berdasarkan gambar ini menunjukkan salah satu faktor penyebab tanah longsor dari faktor manusia. Hal ini berhubungan dengan perkembangan penduduk berdasarkan kecamatan.

Peta Kepadatan Penduduk

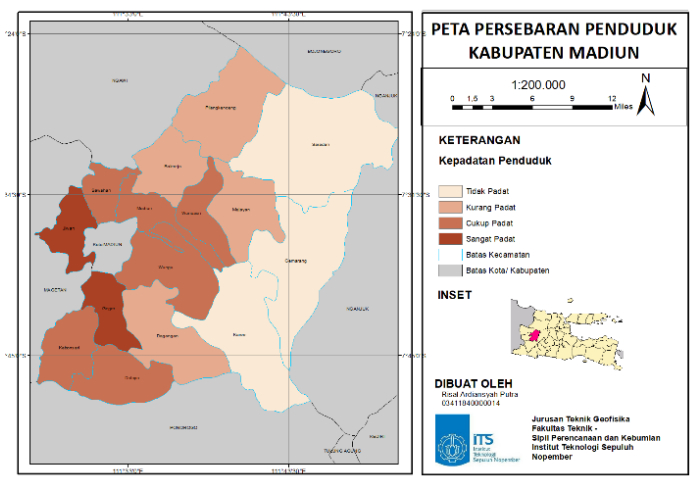

Gambar 5. Peta Kepadatan Penduduk Kabupaten Madiun
Menurut gambar 5 menunjukkan pembagian kepadatan penduduk menjadi empat bagian yaitu tidak padat, kurang padat, cukup padat dan sangat padat. Hal ini didapatkan dari pehitungan kepadatan penduduk yang didapat dari rumus berikut

$$
\text { Kepadatan Penduduk }=\frac{\text { jumlah penduduk }}{\text { luas wilayah }}
$$

Berdasarkan rumus tersebut dihasilkan gambar 5, berdasarkan gambar tersebut menunjukkan bahwa kepadatan penduduk kabupaten Madiun dominan terletak pada daerah sebelah barat kabupaten Madiun. Kepadatan penduduk tertinggi pada kabupaten Madiun terletak pada kecamatan Geger dan Jiwan. Dan kecamatan dengan kepadatan penduduk terendah adalah Karee, Gemarang dan Saradan. 


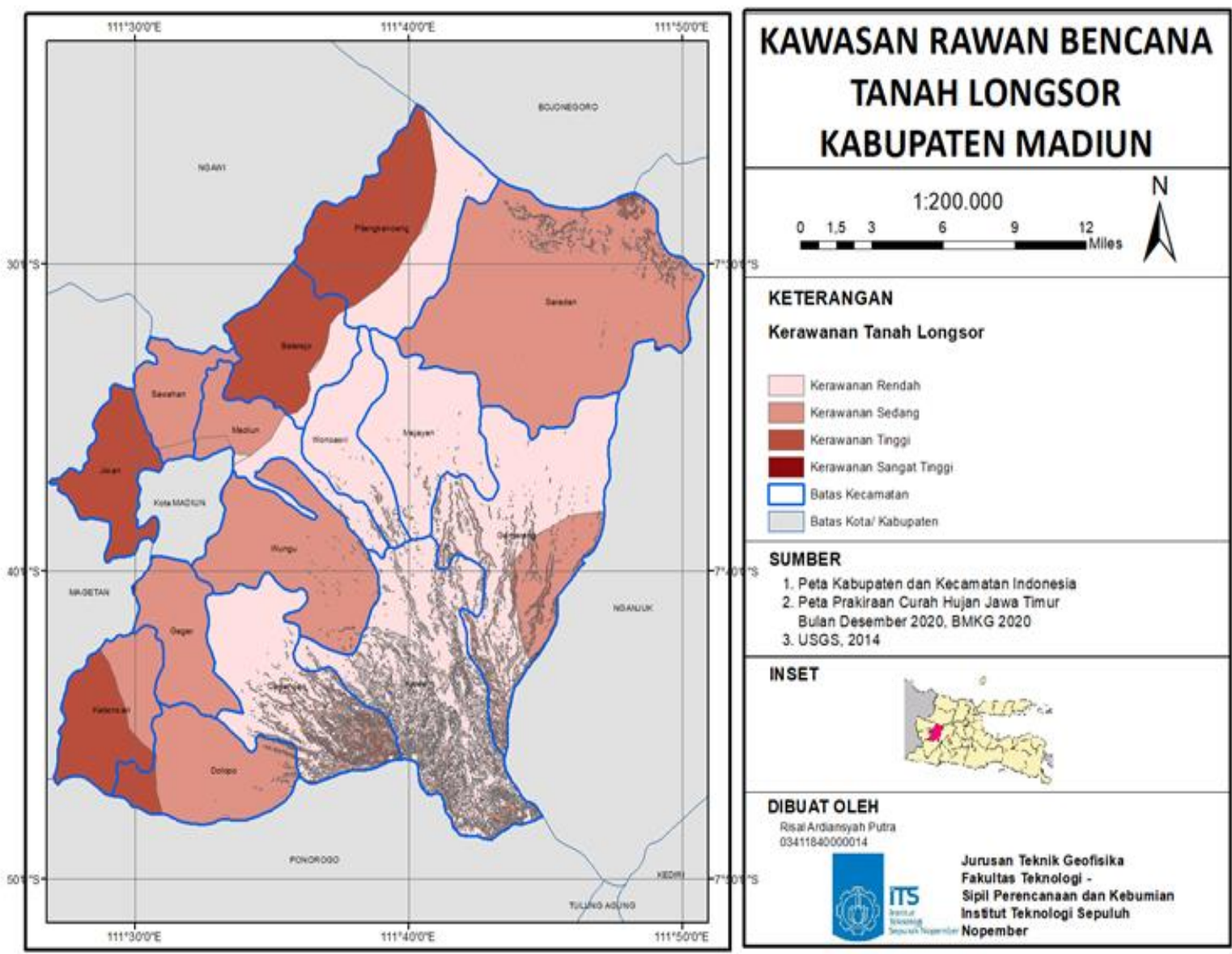

Gambar 6. Gambar Peta Hasil Overlay (Kawasan Rawan Bencana Kabupaten Madiun)

Peta Kawasan Rawan Bencana Tanah Longsor

Berdasarkan gambar 6 menunjukan kawasan rawan bencana Kabupaten Madiun. Berdasarkan hal tersebut kerawanan pada daerah tersebut dibagi menjadi empat bagian dari daerah dengan kerawanan rendah, sedang, tinggi, dan sangat tinggi. Peta overlay ini sendiri didapatkan dari hasil pembobotan dari faktor alam dan faktor manusia dengan pembobotan sebagai berikut. Curah hujan memberikan nilai tertinggi karena tanah longsor sangat berkaitan dengan curah hujan. Seperti halnya yang dibahas pada peta curah hujan semakin tinggi curah hujan maka semakin berpotensi terjadi tanah longsor. Pembobotan tertinggi kedua adalah kemiringan lereng, hal ini disebabkan selain kemiringan lereng merupakan faktor penyebab longsor. Kemiringan lereng juga memiliki faktor yang cukup penting. Jika curah hujan terjadi secara merata pada suatu wilayah, kemiringan lereng dapat menentukannya hal ini dikarenakan semakin tinggi slope lereng maka semakin tinggi terjadi tanah longsor. Jika pada daerah kemiringan lereng dengan slope memiliki curah hujan yang relatif tinggi maka semakin tinggi juga potensi terjadi bencana tanah longsor. Nilai pembobotan terendah adalah kepadatan penduduk, hal ini disebabkan persebaran penduduk terkait dengan korban jiwa jika terjadi bencana longsor, semakin padat suatu maka korban jiwa juga akan meningkat jika terjadi tanah longsor. Berdasarkan gambar 7 menunjukkan bahwa pada daerah Kabupaten Madiun tidak memiliki daerah yang memiliki nilai kerawanan yang sangat tinggi. Akan tetapi pada Kabupaten Madiun terdapat beberapa daerah yang berpotensi 
terjadi tanah longsor seperti pada Kecamatan Pilangkenceng, Balerejo, Jiwan dan sebagian kecamatan Kebonsari dan Dolopo.
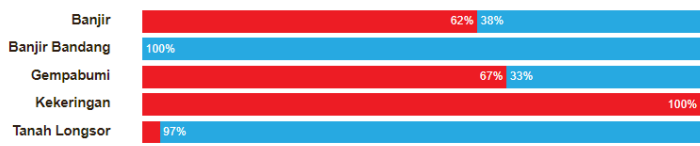

Gambar 7. Bencana Alam Kabupaten Madiun Menurut Inarisk BNPB Indonesia

Hal ini disebabkan pada kecamatankecamatan tersebut memiliki curah hujan yang ekstrem dengan intensitas diata 150 $\mathrm{mm}$, dan juga memiliki kepadatan penduduk yang relatif padat hingga sangat padat. Hal ini juga didukung oleh gambar 7 yang menunjukkan bencana alam yang terjadi di Kabupaten Madiun yang tercatat pada inarisk BNPB Indonesia. Berdasarkan gambar 7 dan tabel 3 menunjukkan bahwa tanah longsor pada Kabupaten Madiun memiliki nilai yang relatif kecil (aman) dengan luas daerah $448.68 \mathrm{~km}^{2}$ untuk kerawanan rendah dan $480.34 \mathrm{~km}^{2}$ untuk kerawanan sedang. Sedangkan daerah yang berpotensi terjadi tanah longsor sebesar $192.07 \mathrm{~km}^{2}$ untuk kerawanan tinggi dan 1.39 $\mathrm{km}^{2}$ untuk kerawanan sangat tinggi.

Tabel 3. Tabel Luas Daerah Kerawanan Tanah Longsor Kabupaten Madiun

\begin{tabular}{lcc}
\hline $\begin{array}{c}\text { KERAWANAN } \\
\text { TANAH LONGSOR }\end{array}$ & $\begin{array}{c}\text { LUAS } \\
\text { DAERAH } \\
\left(\mathbf{k m}^{\mathbf{2}}\right)\end{array}$ & $\begin{array}{c}\text { PERSE } \\
\text { NTASE } \\
\mathbf{( \% )}\end{array}$ \\
\hline Kerawanan Rendah & 448.68191 & 40.02 \\
\hline Kerawanan Sedang & 480.345 & 42.84 \\
\hline Kerawanan Tinggi & 192.0694 & 17.13 \\
\hline $\begin{array}{l}\text { Kerawanan Sangat } \\
\text { Tinggi }\end{array}$ & 1.396 & 0.01 \\
\hline Peta Geologi & & \\
\hline
\end{tabular}
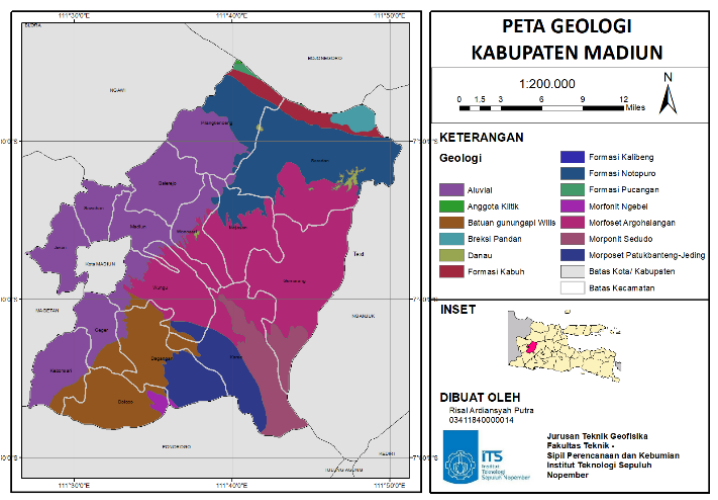

Gambar 9. Peta Geologi Kabupaten Madiun

Berdasarkan gambar 8 menunjukkan peta geologi Kabupaten Madiun. Hal ini dapat menunjukkan bahwa pada kabupaten Madiun didominasi oleh Morfoset Argokalangan yang merupakan morfoset termuda dari Gunung Wilis yang mengandung endapan tefra dan lava andesit horenblenda dengan luas sebesar 314,307 $\mathrm{km}^{2}$. Selain Morfoset Argohalangan pada kabupaten Madiun juga sebagaian besar mengandung aluvial yang memiliki kemampuan infiltrasi yang cukup baik dan juga terdapat kadar mineral dan organisme yang cukup dengan luas sebesar 309,763 $\mathrm{km}^{2}$. Selain itu juga terdapat beberapa geologi lainnya seperti tabel 4 sebagai berikut

Tabel 4. Tabel Luas Daerah Geologi Kabupaten Madiun

\begin{tabular}{ll}
\hline JENIS GEOLOGI & $\begin{array}{l}\text { LUAS DAERAH } \\
\left(\mathbf{k m}^{\mathbf{2}} \mathbf{}\right.\end{array}$ \\
\hline Aluvial & 309.76295 \\
\hline Formasi Kalibeng & 0.00994 \\
\hline Formasi Pucangan & 2.49547 \\
\hline Breksi Pandan & 11.5702 \\
\hline Formasi Kabuh & 24.0455 \\
\hline Formasi Notopuro & 169.137 \\
\hline
\end{tabular}




\begin{tabular}{ll}
\hline JENIS GEOLOGI & $\begin{array}{l}\text { LUAS DAERAH } \\
\left(\mathbf{k m}^{\mathbf{2}}\right)\end{array}$ \\
\hline Morfoset Argohalangan & 314.307 \\
\hline Morfoset Ngebel & 5.04357 \\
\hline Batuan Gunungapi Wilis & 129.291 \\
\hline Morofset Sedudo & 66.7925 \\
\hline $\begin{array}{l}\text { Morfoset Patukbenteng- } \\
\text { Jeding }\end{array}$ & 79.1144 \\
\hline
\end{tabular}

Peta geologi ini dapat mendukung analisis pada gambar 6 yang membuktikan bahwa Kabupaten Madiun memiliki daerah yang relative aman terhadap bencana tanah longsor. Hal ini juga disebabkan secara geologi daerah ini dominan akan Morfoset Argohalangan dan Aluvial yang memiliki potensi tanah longsor kecil karena memiliki kemampuan infiltrasi yang baik sehingga dapat menyerap air dengan baik walaupun dengan curah hujan yang tinggi.

\section{Simpulan}

Berdasarkan Peta Kawasan Rawan Bencana Tanah Longsor yang diolah menggunakan software ArcGis 10.7 berdasarkan parameter tanah longsor seperti peta curah hujan, kemiringan lereng, geologi dan kepadatan penduduk. Didapatkan bahwa pada kabupaten Madiun memiliki kerawanan yang relatif rendah (aman) terhadap tanah longsor. Daerah pada Kabupaten Madiun yang berpotensi terjadi tanah longsor terdapat pada daerah sebelah barat Kabupaten Madiun yaitu Kecamatan Pilangkenceng, Balerejo, Jiwan dan sebagain Kecamatan Kebonsari dan Dolopo dengan luas sebesar sebesar 192.07 $\mathrm{km}^{2}$ untuk kerawanan tinggi dan $1.39 \mathrm{~km}^{2}$ untuk kerawanan sangat tinggi. Hal ini disebabkan pada kecamatan-kecamatan tersebut memiliki curah hujan yang ekstrem dengan intensitas diatas $150 \mathrm{~mm}$, dan juga memiliki kepadatan penduduk yang relatif padat hingga sangat padat.
Saran dari penelitian ini adalah dengan menambahkan beberapa parameter tanah longsor lainnya seperti peta jenis tanah, peta tutupan lahan, peta kerapatan vegetasi dan beberapa parameter yang dapat menentukan peta Kawasan Rawan Bencana Tanah Longsor pada Daerah Kabupaten Madiun.

\section{Daftar Pustaka}

Bakri, S., Murtilaksono, K., \& Barus, B. (2019). Identifikasi Dan Analisis Karakteristik Longsor Di Kabupaten Garut. Jurnal Teknik Sipil, 8(2), 68-78. https://doi.org/10.24815/jts.v8i2.141 17

Buchori, I. (2005). Developing a Spatial Information System for Regional Planning in Indonesia. Vechta: HS Vechta.

Effendi. A. Y. (2016). Pembuatan Peta Daerah Rawan Bencana Tanah Longsor dengan Menggunakan Metode Furzy logic (Studi Kasus: Kabupaten Probolinggo). Jurnal Teknik ITS Vol. 5, No. 2, ISSNn: 2337-3539

Guillard, C. \& Zezere, J. (2012). Landslide Susceptibility Assessment and Validation in The Framework of Municipal Planning in Portugal: The Case of Lourses Municipility. Environmental Management, 50(4), 721735. https://doi.org/10.1007/s00267 $-012-9921-7$

Hardiyatmo. H. C. (2006). Penanganan tanah longsor dan erosi. Gadjah Mada University Press

Kabupaten Madiun. (2019). Review Rpi2-Jm Bidang Cipta Karya Kabupaten Madiun Tahun 2016 - 2019

Kartasapoetra, A. G. (1990). Kerusakan Tanah Pertanian dan Usaha untuk Merehabilitasinya. Jakarta: Bina Aksara.

Monteiro Santos, F.A., Mateus, A., Figueiras, J., \& Gonçalves, M.A. (2006). Mapping Groundwater Contamination around a Landfill Facility using the VLF-EM Method 
- A Case Study. Journal of Applied Geophysics, 60(2), 115-125. https://doi .org/10.1016/j.jappgeo.2006.01.002

Naryanto, H. S. (2013). Analisis dan Evaluasi Kejadian Bencana Tanah Longsor di Cililin, Kabupaten Bandung Barat, Provinsi Jawa Barat Tanggal 25 Maret 2013. JSTMB, 8(1), 39-49.

Rizkianti, C. (2017). Pengarub Kemiringan Lereng terhadap Stabilitas dan Jarak Jangkauan Longsor Setelah Hujan dan Gempa Bumi [Skripsi]. Bandung: Universitas Pendidikan Indonesia.

Susilo, J. (2008). Pengembangan Model SIG Penentuan Kawasan Rawan Longsor Sebagai Masukan Rencana Tata Ruang (Studi Kasus : Kab. Tegal). Tugas Akhir Fakultas Teknik Jurusan Perencanaan
Wilayah dan Kota Semarang : Universitas Diponegoro

Utomo, W. H. (1989). Konservasi Tanah di Indonesia. Jakarta: CV Rajawali.

Pranatasari Dyah Susanti, Arina Miardini, dan B. H. (2017). Jurnal Penelitian Pengelolaan Daerah Aliran Sungai. Analisis Kerentanan Tanab Longsor Sebagai Dasar Mitigasi Di Kabupaten Banjarnegara, 1(1), 49-59.

Susilowati, \& Sadad, I. (2015). Analisa Karakteristik Curah Hujan di Kota Bandar Lampung. Jurnal Konstruksia, 7(1), 13-26.

Yuniarta, H., Saido, A. P., \& Muslih Purwana, Y. (2015). Kerawanan Bencana Tanah Longsor Kabupaten Ponorogo. Matriks Teknik Sipil, 194 201. 